\title{
Preface to the special issue "Strategic applications of real-time risk mitigation strategies and tools: case studies and lessons learned in REAKT"
}

\author{
Carlo Cauzzi $^{1}$ (D) Paolo Gasparini ${ }^{2} \cdot$ Stefan Wiemer $^{1} \cdot$ \\ Jochen Zschau ${ }^{3}$
}

Received: 23 June 2016/Accepted: 26 June 2016/Published online: 1 July 2016

(C) Springer Science+Business Media Dordrecht 2016

Project REAKT (Strategies and Tools for Real-Time Earthquake Risk Reduction, http:// www.reaktproject.eu) was funded in 2011 within the 7th Framework Programme (contract number 282862) of the European Commission. The project concluded at the end of 2014, after 40 months. The main goal of REAKT was to investigate the current limits and improve the efficiency of real-time earthquake risk mitigation methods and their capability of protecting critical structures, infrastructures and the population. To this aim, REAKT gathered the main European institutions and research groups, in addition to major nonEuropean ones, active on different aspects of earthquake early warning (EEW) operational earthquake forecasting (OEF) and real-time structural health monitoring (SHM). One of the work packages of the project, namely "WP7-Strategic Applications and Capacity Building", was devoted to applying and optimising the performance of real-time seismology methods to a variety of critical structures and infrastructures in Europe and worldwide. The strategic applications included: (1) nuclear (Switzerland), hydroelectric (Iceland) and coal (Portugal) power plants; (2) cable stayed (Greece) and suspension bridges (Turkey); (3) electric power (Iceland) and gas distribution (Portugal, Turkey) networks; (4) oil refineries (Portugal); (5) industrial and touristic harbours (Greece, Portugal); vi) railways (Italy); (6) public schools (Italy) and hospitals (Greece). The applications were segregated into feasibility studies, prototype implementation and operational implementation efforts, based on the level of maturity expected to be reached by each application within the project timeline. Important throughout REAKT was the cooperation of academic experts and non-academic (private, public, industrial) end-users/stakeholders aimed at defining work plans for feasibility studies and implementation processes. End-

Carlo Cauzzi

carlo.cauzzi@sed.ethz.ch

Swiss Seismological Service (SED), ETH Zürich, Zurich, Switzerland

2 Department of Physical Sciences, University of Naples Federico II \& AMRA Scarl, Naples, Italy

3 German Research Centre for Geosciences (GFZ), Potsdam, Germany 
user involvement and interaction was seamlessly sought throughout the project and continued after the conclusion of the project. End-user participation was facilitated by the organisation of dedicated events and outreach/dissemination activities comprising conference special sessions and workshops.

We focus in this special volume on the main achievements of the work package, highlighting the most successful application and their key features. The volume comprises three introductory papers devoted to describing the state-of-the-art and depicting a European vision for applications of EEW (Clinton et al. 2016), OEF (Zechar et al. 2016) and structural monitoring based on wireless sensing and computing technologies (Bindi et al. 2016). These topics are further elaborated in seven papers describing selected case studies in REAKT. Cauzzi et al. (2016) present a methodological framework to evaluate the potential benefits and costs of using EEW and OEF for real-time mitigation of seismic risk at nuclear facilities, using Switzerland as a testbed. Emolo et al. (2016) develop a feasibility study on the use of an EEW system for the Campania region (southern Italy) using schools as specific targets. Sokos et al. (2016) discuss the limits and potential of a networkbased EEW system for the city of Patras (Greece), with special focus on the cable stayed bridge between Rion and Antirion. Zülfikar et al. (2016) describe the complex operations of the rapid response and real-time risk mitigation system (IGRAS) for the Istanbul (Turkey) Natural Gas Network (IGDAŞ) triggered by the EEW system maintained by the Kandilli Observatory and Earthquake Research Institute. Zuccolo et al. (2016) focuses on possible applications of EEW to a variety of critical infrastructures in the territories of the Eastern Caribbean using scenario earthquakes, corresponding to the maximum credible earthquakes and to the earthquakes associated with a return period of 475 years. Pitilakis et al. (2016) summarises the ongoing efforts to real-time structural monitoring and EEW to protect a public hospital building in Thessaloniki (Greece) based on permanent and temporary seismic monitoring arrays. Chioccarelli and Iervolino (2015) use three recent seismic sequences in Italy to critically discuss a risk-oriented application of OEF, namely the operational earthquake loss forecasting method MANTIS-K, capable of continuously providing the expected numbers of collapsed buildings, displaced residents and casualties.

EEW was largely tested and critically discussed in REAKT; it is likely that future EEW systems across Europe will "at least partly replicate the first successful examples of REAKT" (Clinton et al. 2016). While a major issue facing core developments and coordination of EEW groups in Europe is that of the short duration of centralised funding from the European Commission, we hope that worldwide successes of EEW will demonstrate to European stakeholders the value of investing in EEW and will eventually stimulate direct private financial support from end-users.

Apparent from the REAKT WP7 experience, a strong potential for OEF is not yet fully developed. While OEF proves very useful to enhance situational awareness in times of heightened earthquake hazard and can support EEW algorithms narrowing the search for earthquake location and magnitude (Cauzzi et al. 2016), its routine application to mitigate seismic risk at structures and infrastructures of public and strategic interest requires solving issues that are today "formidable at least and unsolvable at worst" (Zechar et al. 2016) like, e.g., "heterogeneity: of seismic stations, of data quality and availability, of seismicity rate and faulting styles" (Zechar et al. 2016) along with unstable funding. Even so, there is significant progress, especially in Iceland, Italy and Switzerland. A key to the transfer of OEF from the academic world to strategic applications will be moving from hazard information to statements about risk within the framework of operational earthquake loss forecasting (e.g., Chioccarelli and Iervolino 2015). 
As Guest Editors, we would like to thank all the contributing Authors and Reviewers. We are thankful to the Chief Editor Prof. Atilla Ansal, to the Senior Publishing Editor Petra van Steenbergen and to the former Editorial Assistant Cynthia Clement for their support in the preparation of this special issue. We thank Georgia Cua who originally coordinated the work plans of the REAKT case studies.

\section{References}

Bindi D, Iervolino I, Parolai S (2016) On-site structure-specific real-time risk assessment: perspectives from the REAKT project. Bull Earthq Eng. doi:10.1007/s10518-016-9889-4

Cauzzi C, Behr Y, Le Guenan T et al (2016) Earthquake early warning and operational earthquake forecasting as real-time hazard information to mitigate seismic risk at nuclear facilities. Bull Earthq Eng. doi:10.1007/s10518-016-9864-0

Chioccarelli E, Iervolino I (2015) Operational earthquake loss forecasting: a retrospective analysis of some recent Italian seismic sequences. Bull Earthq Eng. doi:10.1007/s10518-015-9837-8

Clinton J, Zollo A, Marmureanu A et al (2016) State-of-the art and future of earthquake early warning in the European region. Bull Earthq Eng. doi:10.1007/s10518-016-9922-7

Emolo A, Picozzi M, Festa G et al (2016) Earthquake early warning feasibility in the Campania region (southern Italy) and demonstration system for public school buildings. Bull Earthq Eng. doi:10.1007/ s10518-016-9865-z

Pitilakis K, Karapetrou S, Bindi D et al (2016) Structural monitoring and earthquake early warning systems for the AHEPA hospital in Thessaloniki. Bull Earthq Eng. doi:10.1007/s10518-016-9916-5

Sokos E, Tselentis G-A, Paraskevopoulos P et al (2016) Towards earthquake early warning for the RionAntirion bridge, Greece. Bull Earthq Eng. doi:10.1007/s10518-016-9893-8

Zechar JD, Marzocchi W, Wiemer S (2016) Operational earthquake forecasting in Europe: progress, despite challenges. Bull Earthq Eng. doi:10.1007/s10518-016-9930-7

Zuccolo E, Gibbs T, Lai CG et al (2016) Earthquake early warning scenarios at critical facilities in the Eastern Caribbean. Bull Earthq Eng. doi:10.1007/s10518-016-9878-7

Zülfikar C, Erdik M, Safak E et al (2016) Istanbul natural gas network rapid response and risk mitigation system. Bull Earthq Eng. doi:10.1007/s10518-016-9964-x 